\title{
TBXA2R rSNPs, Transcriptional Factor Binding Sites and Asthma in Asians
}

\author{
Norman E. Buroker \\ Department of Pediatrics, University of Washington, Seattle, USA \\ Email: nburoker@u.washington.edu \\ Received 25 January 2014; revised 20 February 2014; accepted 27 February 2014 \\ Copyright (C) 2014 by author and Scientific Research Publishing Inc. \\ This work is licensed under the Creative Commons Attribution International License (CC BY). \\ http://creativecommons.org/licenses/by/4.0/

(c) (i) Open Access

\begin{abstract}
Four regulatory single nucleotide polymorphisms (rSNPs) (rs2238631, rs2238632, rs2238633 and rs2238634) in intron one, two rSNPs (rs1131882 and rs4523) in exon 3 and one rSNP (rs5756) in the 3'UTR of the thromboxane A2 receptor (TBXA2R) gene have been associated with childhoodonset asthma in Asians. These rSNP alleles alter the DNA landscape for potential transcriptional factors (TFs) to attach resulting in changes in transcriptional factor binding sites (TFBS). These TFBS changes are examined with respect to asthma which has been found to be significantly associated with the rSNPs.
\end{abstract}

\section{Keywords}

TBXA2R, rSNPs, TFBS, Asthma

\section{Introduction}

Asthma is a chronic inflammatory condition of the airways characterized by recurrent episodes of reversible airway obstruction and increased bronchial hyper-responsiveness which results from the interactions between genes and environmental factors [1]-[3]. Asthma causes episodes of wheeze, cough, and shortness of breath [4]. Recent studies indicate that the genetic factors of childhood-onset asthma differ from those of adult-onset asthma [3] [5]. Childhood asthma is a major clinical and public health problem as it affects nearly one in eight children in the USA [6] and worldwide [7]. The disease is genetically heterogeneous and genome-wide association studies (GWAS) have identified a group of loci at chromosome 17q21 that are strongly associated with childhoodonset asthma in Caucasians [5] [8]. The genetic origins of asthma are diverse where some disease pathways are specific to wheezing syndromes while others are shared with atopy and bronchial hyper-responsiveness [5]. To that end another gene has recently surfaced in Asian populations that have been found to be associated with lung function childhood-onset asthma [9]. 
The thromboxane A2 receptor (TBXA2R) gene which is located at chromosome 19p13.3 is a member of the seven-transmembrane G-protein-coupled receptor super family, which interacts with intracellular G proteins, regulates different downstream signaling cascades, and induces many cellular responses including the intracellular calcium influx, cell migration and proliferation, and apoptosis [10]. This gene is abundantly expressed in tissues at the mRNA and protein levels targeted by the TBXA2R ligand thromboxane A2 (TXA2) that include erythroleukaemia cells, vascular and bronchial smooth muscle, uterus and placental tissue, endothelium, epithelium, trophoblasts, thymus, liver and small intestine [11]. The activation of TBXA2R in bronchial smooth muscle cells by its ligand results in intercellular calcium mobilization with subsequent bronchoconstriction, which contributes to bronchial smooth muscle hyperplasia and airway remodeling, which occurs in response to chronic airway inflammation in asthma [12].

Four linked TBXA2R single nucleotide polymorphisms (SNPs, rs2238631, rs2238632, rs2238633 and rs2238634) which span a 431bp region of intron one have been found to be in linkage disequilibrium (LD) with two exon 3 SNPs [rs11318632, (c.795 T > C) and rs4523 (c.924 T > C)] [9], which are approximately 8.4 kb downstream from the intron one SNPs. The rs11318632 and rs4523 SNPs from exon 3 are synonymous and unlikely to influence the characteristics of the receptor protein. The exon 3 SNPs have been associated with asthma and its related phenotypes in Asian populations, where rs4523 SNP was found to be associated with adult asthma in a Japanese population [13] and childhood atopic asthma in a Chinese population [14], while the rs11318632 SNP was found to be associated with atopic asthma in a Korean population [15]. Two haplotypes (H2 \& H4) involving the four linked $T B X A 2 R$ SNPs from intron one where found to influence $T B X A 2 R$ transcriptional activity and were also associated with asthma-related phenotypes [9]. This suggests that these SNPs may be part of a regulatory network for the TBXA2R gene in Asian populations. To follow up on this possibility these SNPs were examined for associations to potential transcription factor binding sites (TFBS).

Single nucleotide changes that affect gene expression by impacting gene regulatory sequences such as promoters, enhances, and silencers are known as regulatory SNPs (rSNPs) [16]-[19]. A rSNPs within a transcriptional factor binding site (TFBS) can change a transcriptional factor's (TF) ability to bind its TFBS [20]-[23] in which case the TF would be unable to effectively regulate its target gene [24]-[28]. This concept is examined for the above TBXA2R SNPs and their allelic association with TFBS. In this report, these SNP associations have been discussed with changes in potential TFBS and their possible relationship to childhood-onset asthma in Asians.

\section{Materials and Methods}

\section{Identifying TFBS}

The JASPAR CORE database [29] [30] and ConSite [31] were used to identify the TFBS in this study. JASPAR is a collection of transcription factor DNA-binding preferences used for scanning genomic sequences where ConSite is a web-based tool for finding cis-regulatory elements in genomic sequences. The Vector NTI Advance 11 computer program (Invitrogen, Life Technologies) was used to locate the TFBS in the TBXA2R gene (NCBI Ref Seq NM_201636) from $9.4 \mathrm{~kb}$ upstream of the transcriptional start site to $1.4 \mathrm{~kb}$ past the 3'UTR which represents a total of $17.1 \mathrm{Kbp}$. The JASPAR CORE database was also used to compute each nucleotide occurrence (\%) within the TFBS where upper case lettering indicate that the nucleotide occurs $90 \%$ or greater and lower case less than $90 \%$. The occurrence of each SNP allele in the TFBS is also computed from the database (Table \& Supplement).

\section{Results}

\section{TBXA2RrSNPs and TFBS}

The TBXA2R gene encodes a member of the G protein-coupled receptor family and the protein interacts with thromboxane $\mathrm{A} 2$ to induce platelet aggregation and regulate hemostasis. The activity of this receptor is mediated by a G-protein that activates a phosphatidylinositol-calcium second messenger system. The four TBXA2RrSNPs [rs2238631 (A/G), rs2238632 (C/T), rs2238633 (T/G) and rs2238634 (G/T)] in intron one have been found to be in moderate LD with the exon 3 SNP [rs1131882 (C/T), c.795T > C] while the other exon 3 SNP [rs4523 (C/T), c.924T > C] has been found to be in strong LD with a 3'UTR SNP (rs5756 (C/T) [9]. Since the exon 3 SNPs have been found to be associated with asthma in Asian populations [10]-[12] and certain haplotypes of the intron 
one SNPs have an effect on the transcriptional activity of the TBXA2R gene [9], the potential TFBS for alleles of each of the seven SNPs were examined (Table 1 \& Supplement).

The intron one rs2238631 SNP TBXA2R-A allele creates six unique TFBS for the ELK1 \& 4, ETS1, GATA2, HAND1:TCFC2 $\alpha$ and SPZ1 TFs which are involved in the mitogen-activate protein kinase signaling pathway, repression, controlling development, proliferation of hematopoietic and endocrine cell lineages, and initiation of B lymphopoiesis (Table 1). The intron one rs2238631 SNP TBXA2R-G allele creates two unique TFBS for the FOXC1 and TFAP2 $\alpha$ TFs which are involved in cell viability and resistance to oxidative stress and activating transcription of some genes while inhibiting the transcription of other genes, respectively (Table \& Supplement). Only one TFBS have been conserved between the two rs2238631 alleles which is for the EN1 TF which plays a role in development (Table 1 ).

Table 1. The TBXA2R SNPs that were examined in this study where the minor allele is in red. Also listed are the transcriptional factors (TF), their potential binding sites (TFBS) containing these SNPs and DNA strand orientation. TFs in red differ between the SNP alleles. Where upper case nucleotide designates the $90 \%$ conserved BS region and red is the SNP location of the alleles in the TFBS. Below the TFBS is the nucleotide occurrence (\%) obtained from the Jaspar Core database. Also listed are the number (\#) of binding sites in the gene for the given TF. Note: TFs can bind to more than one nucleotide sequence.

\begin{tabular}{|c|c|c|c|c|c|c|}
\hline SNP & Allele & TFs & Protein name & \# of Sites & TFBS & Strand \\
\hline rs2238631 & A & ELK1 & $\begin{array}{l}\text { ELK1, member of ETS } \\
\text { oncogene family }\end{array}$ & 1 & aagccgGAta & minus \\
\hline (A/G) & & & & & $A=96 \%$ & \\
\hline \multirow[t]{18}{*}{ Intron 1} & & ELK4 & ELK4, ETS-domain protein & 1 & gCCGGAtac & minus \\
\hline & & & & & $A=100 \%$ & \\
\hline & & EN1 & Engrailed homeobox 1 & 1 & acagggtatcc & plus \\
\hline & & & & & $t=30 \%$ & \\
\hline & & ETS1 & Protein C-ets-1 & 1 & taTCCg & plus \\
\hline & & & & & $\mathrm{T}=98 \%$ & \\
\hline & & GATA2 & GATA binding protein 2 & 10 & gGATa & minus \\
\hline & & & & & $A=98 \%$ & \\
\hline & & HAND1:TCFE $2 \alpha$ & $\begin{array}{l}\text { Heart- and neural crest } \\
\text { derivatives-expressed }\end{array}$ & 1 & tatCcGgctt & plus \\
\hline & & & protein 1: transcription factor E2A & & $t=83 \%$ & \\
\hline & & SPZ1 & spermatogenicleucine zipper 1 & 1 & aggGtatccgg & plus \\
\hline & & & & & $t=34 \%$ & \\
\hline & G & EN1 & Engrailed homeobox 1 & 1 & acagggtaccc & plus \\
\hline & & & & & $c=30 \%$ & \\
\hline & & FOXC1 & Forkhead box C1 & 1 & gccggGTA & minus \\
\hline & & & & & $\mathrm{G}=100 \%$ & \\
\hline & & TFAP $2 \alpha$ & Transcription factor AP-2 alpha & 1 & GCCgggtac & minus \\
\hline & & & (activating enhancer binding protein 2 alpha) & & $g=49 \%$ & \\
\hline rs2238632 & C & MAFB & $\begin{array}{l}\text { v-mafmusculoaponeuroticfibrosarcoma } \\
\text { oncogene homolog B (avian) }\end{array}$ & 1 & Ggtgacgc & minus \\
\hline$(\mathrm{C} / \mathrm{T})$ & & & & & $c=34 \%$ & \\
\hline Intron 1 & & PAX2 & Paired box gene 2 & 1 & ggtgacgc & minus \\
\hline
\end{tabular}




\section{Continued}

\begin{tabular}{|c|c|c|c|c|c|c|}
\hline & & & & & $c=35 \%$ & \\
\hline & $\mathbf{T}$ & ARNT & $\begin{array}{l}\text { aryl hydrocarbon receptor nuclear } \\
\text { translocator }\end{array}$ & 5 & gACGTG & minus \\
\hline & & & & & $\mathrm{T}=100 \%$ & \\
\hline & & ARNT & $\begin{array}{l}\text { aryl hydrocarbon receptor nuclear } \\
\text { translocator }\end{array}$ & 6 & cACGTc & plus \\
\hline & & & & & $A=95 \%$ & \\
\hline & & CREB1 & $\begin{array}{l}\text { cAMP responsive element binding } \\
\text { protein } 1\end{array}$ & 1 & gcAcGtca & plus \\
\hline & & & & & $A=100 \%$ & \\
\hline & & HIF1 $\alpha: A R N T$ & Hypoxia-inducible factor & 1 & tgaCGTGc & minus \\
\hline & & & $\begin{array}{l}\text { 1.Aryiny nuccardon } \\
\text { receptor nuclear translocator }\end{array}$ & & $\mathrm{T}=100 \%$ & \\
\hline & & MAFB & $\begin{array}{l}\text { v-mafmusculoaponeuroticfibrosarcoma } \\
\text { oncogene homolog B (avian) }\end{array}$ & 1 & Ggtgacgt & minus \\
\hline & & & & & $t=20 \%$ & \\
\hline & & MAX & MYC associated factor $\mathrm{X}$ & 1 & gagCACGTca & plus \\
\hline & & & & & $A=94 \%$ & \\
\hline & & PAX2 & Paired box gene 2 & 1 & ggtgacgt & minus \\
\hline & & & & & $t=26 \%$ & \\
\hline & & USF1 & Upstream transcription factor 1 & 3 & CACGTca & plus \\
\hline & & & & & $A=100 \%$ & \\
\hline rs2238633 & G & KLF4 & Krueppel-like factor 4 & 1 & aGGGtGgggt & minus \\
\hline$(T / G)$ & & & & & $g=90 \%$ & \\
\hline Intron 1 & & MZF1_1-4 & Myeloid zinc finger 1 & 21 & tGGGGA & minus \\
\hline & & & & & $\mathrm{G}=95 \%$ & \\
\hline & & SP1 & Specificity Protein 1 & 2 & CcCcacCctg & plus \\
\hline & & & & & $c=86 \%$ & \\
\hline & & ZNF354C & Zinc finger protein 354C & 31 & сcсCAC & plus \\
\hline & & & & & $c=38 \%$ & \\
\hline & $\mathbf{T}$ & BRCA1 & breast cancer 1 , early onset & 5 & acAccac & plus \\
\hline & & & & & $A=95 \%$ & \\
\hline & & EN1 & Engrailed homeobox 1 & 1 & gggtggtgtcg & minus \\
\hline & & & & & $t=70 \%$ & \\
\hline & & KLF4 & Krueppel-like factor 4 & 1 & aGGGtGgtgt & minus \\
\hline & & & & & $t=3 \%$ & \\
\hline & & ZNF354C & Zinc finger protein 354C & 37 & cacCAC & plus \\
\hline & & & & & $\mathrm{a}=44 \%$ & \\
\hline rs2238634 & $\mathbf{T}$ & HLTF & Helicase-like transcription factor & 1 & gagCtTagca & minus \\
\hline
\end{tabular}




\section{Continued}

(G/T)

Intron 1

HNF4 $\alpha$

Hepatocyte nuclear factor 4, alpha

NR2F1

Nuclear receptor subfamily 2, group $\mathrm{F}$, member 1

NR2E3

NR2E3

NR4A2

ZFX

G

ZFX

GATA2

GATA binding protein 2

(C/T)

c.795T > C

Exon 3

$\mathbf{T}$

$\begin{array}{cl}\text { MZF1_1-4 } & \text { Myeloid zinc finger } 1 \\ \text { MZF1_5-13 } & \text { Myeloid zinc finger 1 } \\ \text { NFIC } & \text { Nuclear factor 1 C-type } \\ \text { NKX2-5 } & \text { Natural killer 2 homeobox } 5 \\ & \\ \text { Nobox } & \text { NOBOX oogenesis homeobox }\end{array}$

Nuclear receptor subfamily 2, group E, member 3

Nuclear receptor subfamily 2, group $\mathrm{E}$, member 3

Nuclear receptor subfamily 4, group A, member 2

INSM1

Insulinoma-associated 1

2-related factor 1

Transcription factor MafG

NFIC Nuclear factor 1 C-type

$$
\mathrm{T}=100 \%
$$

1

gGtgCtaAGctca

plus

$$
\mathrm{a}=79 \%
$$

1

tGAgCttagcaccc

minus

$$
t=85 \%
$$

3

$\operatorname{tgAGCTT}$

minus

$\mathrm{T}=100 \%$

tAAGCTC

plus

$$
A=100 \%
$$

aAGctCAg plus

$a=57 \%$

1 taagctcaGGCCTc plus

$$
\mathrm{a}=12 \%
$$

1 tcagctcaGGCCTc plus $\mathrm{c}=35 \%$

10 cGATg plus $\mathrm{G}=91 \%$

3 cGATga

plus

$$
\mathrm{G}=98 \%
$$

1

tgtctGGGcgat

plus

$g=67 \%$

4

24

gaTGAa

plus

$g=29 \%$

tgGGcg

plus

$g=17 \%$

14

tGGGcA

plus

$A=90 \%$

gtctGGGcaa

plus

$$
\mathrm{a}=63 \%
$$

14

tgGGca

plus

$\mathrm{a}=48 \%$

2

ttcAttg

$t=65 \%$

1
TcATtgcc

minus 


\section{Continued}

\begin{tabular}{|c|c|c|c|c|c|c|}
\hline & & & & & $t=84 \%$ & \\
\hline & & PAX2 & Paired box gene 2 & 1 & cttCattg & minus \\
\hline & & & & & $t=32 \%$ & \\
\hline & & SOX17 & SRY (sex determining region Y)-box 17 & 1 & ttcaTTGcc & minus \\
\hline & & & & & $\mathrm{T}=100 \%$ & \\
\hline rs4523 & C & AR & Androgen receptor & 1 & gggtGtACatcctGttCcgccg & minus \\
\hline$(\mathrm{C} / \mathrm{T})$ & & & & & $C=100 \%$ & \\
\hline c.924T > C & & ELF5 & E74-like factor 5 & 1 & tacaTCCtg & minus \\
\hline Exon 3 & & & & & $c=45 \%$ & \\
\hline & & ELK1 & ELK1, member of ETS oncogene family & 1 & gaacagGAtg & plus \\
\hline & & & & & $g=50 \%$ & \\
\hline & & ELK4 & ELK4, ETS-domain protein & 1 & aCaGGAtgt & plus \\
\hline & & & & & $g=75 \%$ & \\
\hline & & ETS1 & Protein C-ets-1 & 15 & caTCCt & minus \\
\hline & & & & & $c=40 \%$ & \\
\hline & & FEV & ETS oncogene family & 1 & caGGAtgt & plus \\
\hline & & & & & $g=46 \%$ & \\
\hline & & FOXC1 & Forkhead box C1 & 2 & aggatGTA & plus \\
\hline & & & & & $G=100 \%$ & \\
\hline & & GATA2 & GATA binding protein 2 & 32 & gGATg & plus \\
\hline & & & & & $g=28 \%$ & \\
\hline & & NR3C1 & $\begin{array}{l}\text { Nuclear receptor subfamily 3, } \\
\text { group C, member } 1 \\
\text { (glucocorticoid receptor) }\end{array}$ & 1 & $\begin{array}{c}\text { gtgtacAtcctGTtCcgc } \\
\qquad \mathrm{c}=67 \%\end{array}$ & minus \\
\hline & & SPI1 & $\begin{array}{l}\text { Spleen focus forming virus (SFFV) } \\
\text { proviral integration oncogene spi1 }\end{array}$ & 3 & aGGATgt & plus \\
\hline & & & & & $g=79 \%$ & \\
\hline & $\mathbf{T}$ & ELF5 & E74-like factor 5 & 1 & tataTCCtg & minus \\
\hline & & & & & $\mathrm{t}=45 \%$ & \\
\hline & & ELK1 & ELK1, member of ETS oncogene family & 1 & gaacagGAta & plus \\
\hline & & & & & $\mathrm{a}=50 \%$ & \\
\hline & & ETS1 & Protein C-ets-1 & 3 & taTCCt & minus \\
\hline & & & & & $t=14 \%$ & \\
\hline & & FEV & ETS oncogene family & 1 & caGGAtat & plus \\
\hline & & & & & $\mathrm{a}=54 \%$ & \\
\hline & & FOXL1 & Forkhead box L1 & 1 & aggatATA & plus \\
\hline & & & & & $A=91 \%$ & \\
\hline
\end{tabular}




\section{Continued}

\begin{tabular}{|c|c|c|c|c|c|c|}
\hline & & GATA2 & GATA binding protein 2 & 10 & gGATa & plus \\
\hline & & & & & $a=28 \%$ & \\
\hline & & GATA3 & GATA binding protein 3 & 2 & gGATat & plus \\
\hline & & & & & $a=62 \%$ & \\
\hline & & KLF4 & Krueppel-like factor 4 & 1 & tGGGtGtata & minus \\
\hline & & & & & $t=7 \%$ & \\
\hline & & ZNF354C & Zinc finger protein 354C & 4 & ataCAC & plus \\
\hline & & & & & $a=44 \%$ & \\
\hline rs5756 & C & ARNT:AHR & aryl hydrocarbon receptor & & gGCGTG & plus \\
\hline$(\mathrm{C} / \mathrm{T})$ & & & aryl hydrocarbon receptor & 20 & $G=96 \%$ & \\
\hline 3'UTR & & BRCA1 & breast cancer 1 , early onset & 22 & ссАссас & minus \\
\hline & & & & & $c=51 \%$ & \\
\hline & & EN1 & Engrailed homeobox 1 & 5 & gcgtggtggcg & plus \\
\hline & & & & & $g=70 \%$ & \\
\hline & & HIF1 $\alpha: A R N T$ & $\begin{array}{l}\text { Hypoxia-inducible factor } 1 \text { : } \\
\text { Aryl hydrocarbon receptor nuclear translocator }\end{array}$ & 10 & gggCGTGg & plus \\
\hline & & & & & $G=100 \%$ & \\
\hline & & KLF4 & Krueppel-like factor 4 & 4 & cGGGcGtggt & plus \\
\hline & & & & & $\mathrm{G}=98 \%$ & \\
\hline & & PAX2 & Paired box gene 2 & 9 & cacCacgc & minus \\
\hline & & & & & $c=55 \%$ & \\
\hline & & TFAP2A & $\begin{array}{l}\text { Transcription factor AP-2 alpha } \\
\text { (activating enhancer binding }\end{array}$ & 8 & GCCaccacg & minus \\
\hline & & & protein 2 alpha) & & $c=9 \%$ & \\
\hline & & TFAP2A & $\begin{array}{l}\text { Transcription factor AP-2 alpha } \\
\text { (activating enhancer binding }\end{array}$ & 5 & GCCgggegt & plus \\
\hline & & & protein 2 alpha) & & $g=74 \%$ & \\
\hline & & ZNF354C & Zinc finger protein 354C & 37 & саССАС & minus \\
\hline & & & & & $C=94 \%$ & \\
\hline & $\mathbf{T}$ & NFIC & Nuclear factor 1 C-type & 18 & cgGGca & plus \\
\hline & & & & & $a=48 \%$ & \\
\hline & & NFE2L1:MAFG & $\begin{array}{l}\text { Nuclear factor erythroid 2-related } \\
\text { factor } 1 \text { Transcription factor MafG }\end{array}$ & 20 & caTGcc & minus \\
\hline & & & & & $\mathrm{T}=100 \%$ & \\
\hline & & TFAP2A & $\begin{array}{l}\text { Transcription factor AP-2 alpha } \\
\text { (activating enhancer binding }\end{array}$ & 8 & GCCaccatg & minus \\
\hline & & & protein 2 alpha) & & $t=7 \%$ & \\
\hline & & ZEB1 & Zinc finger E-box binding homeobox 1 & 22 & cACCat & minus \\
\hline & & & & & $t=34 \%$ & \\
\hline & & YY1 & YY1 transcription factor & 22 & aCCATg & minus \\
\hline & & & & & $\mathrm{T}=100 \%$ & \\
\hline
\end{tabular}


The intron one rs2238632 SNP TBXA2R-C allele creates no unique TFBS while the TBXA2R -T allele creates five unique TFBS which are for the ARNT, CREB1, HIF1 $\alpha$ :ARNT, MAX and USF1 TFs which are involved with xenobiotic metabolism, circadian rhythmicity, cellular and systemic responses to hypoxia, transcriptional regulator and a cellular TF, respectively (Table \& Supplement). Two TFBS have been conserved between the two alleles which are the MAFB and PAX2 TFs that are involved with the transcription of erythroid-specific genes in myeloid cells and plays a role in kidney cell development, respectively (Table 1).

The intron one rs2238633 SNP TBXA2R-G allele creates two unique TFBS for the MZF1_1-4 and SP1 TFs which are involved in transcriptional regulation and the regulation of genes involved in cell growth, apaoptosis, differentiation and immune responses, respectively (Table \& Supplement). The intron one rs2238633 SNP $T B X A 2 R$-T allele also creates two unique TFBS for the BRCA1 and SP1 TFs which are involved in maintaining genomic stability and controlling development, respectively (Table \& Supplement). Two TFBS have been conserved between the two alleles which are the KLF4 and ZNF354C TFs that are involved with the regulation of key transcription factors during embryonic development, activation and repression, respectively (Table \& Supplement).

The intron one rs2238634 SNP TBXA2R-T allele creates five unique TFBS for the HLTF, HNF4 $\alpha$, NR2F1, NR2E3 and NR4A2 TFs which are involved with altering chromatin structure, regulates the expression of hepatic genes, initiation of transcription, signaling pathways and transcription regulation, respectively (Table \& Supplement). The intron one rs2238634 SNP TBXA2R-G allele creates no unique TFBS. One TFBS has been conserved between the two alleles which is the ZFX TF which is a probable transcription activator.

The exon 3 rs1131882 SNP TBXA2R-C allele creates four unique TFBS for the GATA2, GATA3, INSM1 and NFE2L.1: MAFG TFs which are involved with regulation of genes for development and proliferation of hematopoietic and endocrine cell lineages, endothelial cell biology, neuroendocrine differentiation of human lung tumors, and up-regulation of cytoprotective genes via the antioxidant response element, respectively (Table \& Supplement). The exon 3 rs1131882 SNP TBXA2R-T allele creates six unique TFBS for the MZF1_1-4, MZF1_5-13, NKX2-5, Nobox, PAX2 and SOX17 TFs which are involved with transcription regulation, negative regulator of chondrocyte maturation, oogenesis and kidney cell differentiation (Table \& Supplement). One TFBS has been conserved between the two alleles which is the NFIC TF which is involved with activating transcription and replication.

The exon 3 rs4523 SNP TBXA2R-C allele creates five unique TFBS for the AR, ELK4, FOXC1, NR3C1 and SPI1 TFs which are involved with the regulation of eukaryotic gene expression, transcriptional activation and repression, viability and resistance to oxidative stress, regulation of carbohydrate, protein and fat metabolism as well as activating gene expression during myeloid and B-lymphoid cell development, respectively (Table \& Supplement). The exon 3 rs4523 SNP TBXA2R-T allele creates four unique TFBS for the FOXL1, GATA3, KLF4 and ZNF354C TFs which are involved with the regulation of multiple processes including metabolism, cell proliferation and gene expression during ontogenesis, endothelial cell biology, embryonic development and transcription repression, respectively (Table \& Supplement). Five TFBS have been conserved between the two alleles which are the ELF5, ELK1, ETS1, FEV and GATA2 TFs that are involved with regulation epitheliumspecific genes, the mitogen-activate protein kinase signaling pathway, the TTRAP, UBE2I and Death associated protein, transcriptional repression and genes for development and proliferation of hematopoietic and endocrine cell lineages (Table \& Supplement).

The 3'UTR rs5756 SNP TBXA2R-C allele creates seven unique TFBS for the ARNT:AHR, BRCA1, EN1, HIF1 $\alpha$ :ARNT, KLF4, PAX2 and ZNF354C TFs which are involved with xenobiotic metabolism, genomic stability, controlling development, hypoxia, embryonic development, kidney cell differentiation and repression, respectively (Table \& Supplement). The 3'UTR rs5756 SNP TBXA2R-T allele creates four unique TFBS for the NFIC, NFE2L1:MAFG, ZEB1 and YY1 TFs which are involved with activating transcription and replication, up-regulation of cytoprotective genes, transcription repression and control of transcription, respectively (Table \& Supplement). Only one TFBS has been conserved between the two alleles which is the TFAP2 $\alpha$ that is involved with controlling transcription.

\section{Discussion}

GWAS over the last decade have identified nearly 6500 disease or trait-predisposing SNPs where only $7 \%$ of these are located in protein-coding regions of the genome [32] [33] and the remaining 93\% are located within 
non-coding areas [34] [35] such as regulatory or intergenic regions. SNPs which occur in the putative regulatory region of a gene where a single base change in the DNA sequence of a potential TFBS may affect the process of gene expression are drawing more attention [16] [18] [36]. A SNP in a TFBS can have multiple consequences. Often the SNP does not change the TFBS interaction nor does it alter gene expression since a transcriptional factor (TF) will usually recognize a number of different binding sites in the gene. In some cases the SNP may increase or decrease the TF binding which results in allele-specific gene expression. In rare cases, a SNP may eliminate the natural binding site or generate a new binding site. In which cases the gene is no longer regulated by the original TF. Therefore, functional rSNPs in TFBS may result in differences in gene expression, phenotypes and susceptibility to environmental exposure [36]. Examples of rSNPs associated with disease susceptibility are numerous and several reviews have been published [36]-[39].

GWAS have also identified many potential rSNPs and candidate genes associated with the asthma [5] [8] [40] [41], which indicates that the genetic origins of the disease are extremely diverse [5]. The EVE consortium conducted a meta-analysis of North American GWAS including individuals of European American, African American or African Caribbean and Latino ancestry. The study revealed that previously identified loci on chromosome 17q21 (encoding ORMDL3 and GSDMB) [8] and the nearby IL1RL1, TSLP and IL33 genes were robust to ethnic differences and had significant associations in all three ethnic groups [42]. The same study also identified another asthma susceptibility locus at PYHIN1, with the association being specific to individuals of African descent. The associated SNPs in PYHIN1 occur with a minor allele frequencies of 0.26 - 0.29 in African-Americans and African-Caribbean controls, less than 0.05 in the Latino populations and not polymorphic in European Americans [42]. Yet another asthma susceptibility locus at TBXA2R has been associated with childhood-onset in Asians [9] which has been the focus of this report.

In this study the intron one rs2238631 TBXA2R-A minor allele [T (+ strand) or A (-strand)] located in the ELK1, ELK4, ETS1 and HAND1:TCFE2 $\alpha$ TFBS has a 96\%, 100\%, 98\% and 83\% occurrence, respectively, in humans. These BS occurs only once in the gene and therefore a change in these TFBS created by this rSNP would probably have any impact on the regulation of the gene (Table \& Supplement). In contrast, the intron one rs2238631 TBXA2R-A allele located in the SPZ1 TFBS has a 34\% occurrence and also only occurs once in the gene which might not have much of an impact on the regulation of the gene since other nucleotides can be substituted at this position. Also, the intron one rs2238631 TBXA2R-A allele located in the GATA2 TFBS has a 98\% occurrence but occurs nine other times in the gene; therefore, it might not have much of an impact on gene regulation. The rs2238631 TBXA2R-G common allele [C (+ strand) or G (-strand)] located in the FOXC1 and TFAP2 $\alpha$ TFBS has a 100\% and 49\% occurrence in humans and these BS occur only once in the gene and therefore a change in these TFBS created by this rSNP would probably have any impact on the regulation of the gene for the FOXC1 TF but not much impact for the TFAP2 $\alpha$ TF (Table \& Supplement). The arrangement of these TFBS within various haplotypes might explain the LD found between these TBXA2R rSNPs [9].

Similar logic can be used to evaluate the potential TFBS within the other TBXA2R rSNPs found in the table. It should be noted that the minor alleles in the intron 1 rSNPs create more unique TFBS than do the common alleles by a ratio of 18 to 4, respectively (Table 1 ) while the same ratio for the exon 3 and 3'UTR rSNPs is 13 to 17. Unique TFBSs that would be expected to have an impact on asthma are ELK1 and SPZ1 created by the minor allele of rs2238631, HIF1 $\alpha$ :ARNT created by the minor allele of rs2238632, INSM1 created by the minor allele of rs1131882 and FOXC1 created by the minor allele of rs4523. Other unique TFBS that would be expected to have an impact on asthma which are created by the rSNP common alleles would be FOXC1 (rs2238631) and HIF1 $\alpha$ :ARNT (rs5756). The two haplotypes (H2 \& H4) involving the four linked TBXA2R SNPs from intron one found to influence $T B X A 2 R$ transcriptional activity and were also associated with asthma-related phenotypes [9] involving the minor alleles of rs2238631 and rs2238632 which create the unique TFBS for the ELK1, SPZ1 and HIF1 $\alpha$ :ARNT, respectively. Also that worth mentioning would be the minor allele of rs2238634 which creates the NR2E3 TFBS whose TF is involved with signaling pathways (Table \& Supplement).

The changes in biological and physiological conditions that have been associated with these rSNPs of the $T B X A 2 R$ gene are shown in the table and supplement along with rSNP allele-specific TFBS. What a change in the rSNP alleles can do is to alter the DNA landscape around the SNP for potential TFs to attach and regulate a gene. This change in the DNA landscape can alter gene regulation which in turn can result in a change of a biological process or signaling pathway resulting in disease or illness. In this report, the seven rSNPs of the $T B X A 2 R$ gene which have been examined illustrate that a change in rSNP alleles can provide different TFBS 
which in turn could also be associated with asthma.

\section{Conflict of Interest}

Author declares that there is no conflict of interests.

\section{References}

[1] Martinez, F.D. and Vercelli, D. (2013) Asthma. Lancet, 382, 1360-1372. http://dx.doi.org/10.1016/S0140-6736(13)61536-6

[2] Dijk, F.N., de Jongste, J.C., Postma, D.S. and Koppelman, G.H. (2013) Genetics of Onset of Asthma. Current Opinion in Allergy \& Clinical Immunology, 13, 193-202. http://dx.doi.org/10.1097/ACI.0b013e32835eb707

[3] Mantzouranis, E., Papadopouli, E. and Michailidi, E. (2014) Childhood Asthma: Recent Developments and Update. Current Opinion in Pulmonary Medicine, 20, 8-16. http://dx.doi.org/10.1097/MCP.000c0000000000014

[4] Papadopoulos, N.G., Arakawa, H., Carlsen, K.H., Custovic, A., Gern, J., Lemanske, R., Le Souef, P., Makela, M., Roberts, G., Wong, G., Zar, H., Akdis, C.A., Bacharier, L.B., Baraldi, E., van Bever, H.P., de Blic, J., Boner, A., Burks, W., Casale, T.B., Castro-Rodriguez, J.A., Chen, Y.Z., El-Gamal, Y.M., Everard, M.L., Frischer, T., Geller, M., Gereda, J., Goh, D.Y., Guilbert, T.W., Hedlin, G., Heymann, P.W., Hong, S.J., Hossny, E.M., Huang, J.L., Jackson, D.J., de Jongste, J.C., Kalayci, O., Ait-Khaled, N., Kling, S., Kuna, P., Lau, S., Ledford, D.K., Lee, S.I., Liu, A.H., Lockey, R.F., Lodrup-Carlsen, K., Lotvall, J., Morikawa, A., Nieto, A., Paramesh, H., Pawankar, R., Pohunek, P., Pongracic, J., Price, D., Robertson, C., Rosario, N., Rossenwasser, L.J., Sly, P.D., Stein, R., Stick, S., Szefler, S., Taussig, L.M., Valovirta, E., Vichyanond, P., Wallace, D., Weinberg, E., Wennergren, G., Wildhaber, J. and Zeiger, R.S. (2012) International Consensus on (ICON) Pediatric Asthma. Allergy, 67, 976-997. http://dx.doi.org/10.1111/j.1398-9995.2012.02865.X

[5] Spycher, B.D., Henderson, J., Granell, R., Evans, D.M., Smith, G.D., Timpson, N.J. and Sterne, J.A. (2012) GenomeWide Prediction of Childhood Asthma and Related Phenotypes in a Longitudinal Birth Cohort. Journal of Allergy and Clinical Immunology, 130, 503-509.

[6] Akinbami, L. (2006) The State of Childhood Asthma, United States, 1980-2005. Advanced Data, 381, 1-24.

[7] Lai, C.K., Beasley, R., Crane, J., Foliaki, S., Shah, J. and Weiland, S. (2009) Global Variation in the Prevalence and Severity of Asthma Symptoms: Phase Three of the International Study of Asthma and Allergies in Childhood (ISAAC). Thorax, 64, 476-483. http://dx.doi.org/10.1136/thx.2008.106609

[8] Moffatt, M.F., Kabesch, M., Liang, L., Dixon, A.L., Strachan, D., Heath, S., Depner, M., von Berg, A., Bufe, A., Rietschel, E., Heinzmann, A., Simma, B., Frischer, T., Willis-Owen, S.A., Wong, K.C., Illig, T., Vogelberg, C., Weiland, S.K., von Mutius, E., Abecasis, G.R., Farrall, M., Gut, I.G., Lathrop, G.M. and Cookson, W.O. (2007) Genetic Variants Regulating ORMDL3 Expression Contribute to the Risk of Childhood Asthma. Nature, 448, 470-473. http://dx.doi.org/10.1038/nature06014

[9] Takeuchi, K., Mashimo, Y., Shimojo, N., Arima, T., Inoue, Y., Morita, Y., Sato, K., Suzuki, S., Nishimuta, T., Watanabe, H., Hoshioka, A., Tomiita, M., Yamaide, A., Watanabe, M., Okamoto, Y., Kohno, Y., Hata, A. and Suzuki, Y. (2013) Functional Variants in the Thromboxane A2 Receptor Gene Are Associated with Lung Function in ChildhoodOnset Asthma. Clinical \& Experimental Allergy, 43, 413-424. http://dx.doi.org/10.1111/cea.12058

[10] Huang, J.S., Ramamurthy, S.K., Lin, X. and Le Breton, G.C. (2004) Cell Signalling through Thromboxane A2 Receptors. Cell Signal, 16, 521-533. http://dx.doi.org/10.1016/j.cellsig.2003.10.008

[11] Miggin, S.M. and Kinsella, B.T. (1998) Expression and Tissue Distribution of the mRNAs Encoding the Human Thromboxane A2 Receptor (TP) Alpha and Beta Isoforms. Biochimica et Biophysica Acta, 1425, 543-559. http://dx.doi.org/10.1016/S0304-4165(98)00109-3

[12] Rolin, S., Masereel, B. and Dogne, J.M. (2006) Prostanoids as Pharmacological Targets in COPD and Asthma. European Journal of Pharmacology, 533, 89-100. http://dx.doi.org/10.1016/j.ejphar.2005.12.058

[13] Unoki, M., Furuta, S., Onouchi, Y., Watanabe, O., Doi, S., Fujiwara, H., Miyatake, A., Fujita, K., Tamari, M. and Nakamura, Y. (2000) Association Studies of 33 Single Nucleotide Polymorphisms (SNPs) in 29 Candidate Genes for Bronchial Asthma: Positive Association a T924C Polymorphism in the Thromboxane A2 Receptor Gene. Human Genetics, 106, 440-446. http://dx.doi.org/10.1007/s004390000267

[14] Leung, T.F., Tang, N.L., Lam, C.W., Li, A.M., Chan, I.H. and Ha, G. (2002) Thromboxane A2 Receptor Gene Polymorphism Is Associated with the Serum Concentration of Cat-Specific Immunoglobulin E as Well as the Development and Severity of Asthma in Chinese Children. Pediatric Allergy and Immunology, 13, 10-17. http://dx.doi.org/10.1034/j.1399-3038.2002.01033.x

[15] Shin, H.D., Park, B.L., Jung, J.H., Wang, H.J., Park, H.S., Choi, B.W., Hong, S.J., Lee, Y.M., Kim, Y.H. and Park, C.S. (2003) Association of Thromboxane A2 Receptor (TBXA2R) with Atopy and Asthma. Journal of Allergy and Clinical 
Immunology, 112, 454-457. http://dx.doi.org/10.1067/mai.2003.1641

[16] Knight, J.C. (2003) Functional Implications of Genetic Variation in Non-Coding DNA for Disease Susceptibility and Gene Regulation. Clinical Science, 104, 493-501. http://dx.doi.org/10.1042/CS20020304

[17] Knight, J.C. (2005) Regulatory Polymorphisms Underlying Complex Disease Traits. Journal of Molecular Medicine, 83, 97-109. http://dx.doi.org/10.1007/s00109-004-0603-7

[18] Wang, X., Tomso, D.J., Liu, X. and Bell, D.A. (2005) Single Nucleotide Polymorphism in Transcriptional Regulatory Regions and Expression of Environmentally Responsive Genes. Toxicology and Applied Pharmacology, 207, 84-90. http://dx.doi.org/10.1016/j.taap.2004.09.024

[19] Wang, X., Tomso, D.J., Chorley, B.N., Cho, H.Y., Cheung, V.G., Kleeberger, S.R. and Bell, D.A. (2007) Identification of Polymorphic Antioxidant Response Elements in the Human Genome. Human Molecular Genetics, 16, 1188-1200. http://dx.doi.org/10.1093/hmg/ddm066

[20] Claessens, F., Verrijdt, G., Schoenmakers, E., Haelens, A., Peeters, B., Verhoeven, G. and Rombauts, W. (2001) Selective DNA Binding by the Androgen Receptor as a Mechanism for Hormone-Specific Gene Regulation. The Journal of Steroid Biochemistry and Molecular Biology, 76, 23-30.

[21] Hsu, M.H., Savas, U., Griffin, K.J. and Johnson, E.F. (2007) Regulation of Human Cytochrome P450 4F 2 Expression by Sterol Regulatory Element-Binding Protein and Lovastatin. Journal of Biological Chemistry, 282, 5225-5236. http://dx.doi.org/10.1074/jbc.M608176200

[22] Takai, H., Araki, S., Mezawa, M., Kim, D.S., Li, X.Y., Yang, L., Li, Z.Y., Wang, Z.T., Nakayama, Y. and Ogata, Y. (2008) AP1 Binding Site Is Another Target of FGF2 Regulation of Bone Sialoprotein Gene Transcription. Gene, 410, 97-104. http://dx.doi.org/10.1016/j.gene.2007.11.017

[23] Buroker, N.E., Huang, J.Y., Barboza, J., Ledee, D.R., Eastman Jr., R.J., Reinecke, H., Ning, X.H., Bassuk, J.A. and Portman, M.A. (2012) The Adaptor-Related Protein Complex 2, Alpha 2 Subunit (AP2 $\alpha 2$ ) Gene Is a Peroxisome Proliferator-Activated Receptor Cardiac Target Gene. The Protein Journal, 31, 75-83. http://dx.doi.org/10.1007/s10930-011-9379-0

[24] Huang, C.N., Huang, S.P., Pao, J.B., Hour, T.C., Chang, T.Y., Lan, Y.H., Lu, T.L., Lee, H.Z., Juang, S.H., Wu, P.P., Huang, C.Y., Hsieh, C.J. and Bao, B.Y. (2012) Genetic Polymorphisms in Oestrogen Receptor-Binding Sites Affect Clinical Outcomes in Patients with Prostate Cancer Receiving Androgen-Deprivation Therapy. Journal of Internal Medicine, 271, 499-509. http://dx.doi.org/10.1111/j.1365-2796.2011.02449.x

[25] Huang, C.N., Huang, S.P., Pao, J.B., Chang, T.Y., Lan, Y.H., Lu, T.L., Lee, H.Z., Juang, S.H., Wu, P.P., Pu, Y.S., Hsieh, C.J. and Bao, B.Y. (2012) Genetic Polymorphisms in Androgen Receptor-Binding Sites Predict Survival in Prostate Cancer Patients Receiving Androgen-Deprivation Therapy. Annals of Oncology: Official Journal of the European Society for Medical Oncology/ESMO, 23, 707-713.

[26] Yu, B.L., Lin, H.L., Yang, L.X., Chen, K., Luo, H.H., Liu, J.Q., Gao, X.C., Xia, X.F. and Huang, Z.F. (2012) Genetic Variation in the Nrf2 Promoter Associates with Defective Spermatogenesis in Humans. Journal of Molecular Medicine, 90, 1333-1342. http://dx.doi.org/10.1007/s00109-012-0914-z

[27] Wu, J.M., Richards, M.H., Huang, J.H., Al-Harthi, L., Xu, X.L., Lin, R., Xie, F.L., Gibson, A.W., Edberg, J.C. and Kimberly, R.P. (2011) Human FasL Gene Is a Target of $\beta$-Catenin/T-Cell Factor Pathway and Complex FasL Haplotypes Alter Promoter Functions. PLoS ONE, 6, Article ID: e26143. http://dx.doi.org/10.1371/journal.pone.0026143

[28] Alam, M., Pravica, V., Fryer, A.A., Hawkins, C.P. and Hutchinson, I.V. (2005) Novel Polymorphism in the Promoter Region of the Human Nerve Growth-Factor Gene. International Journal of Immunogenetics, 32, 379-382. http://dx.doi.org/10.1111/j.1744-313X.2005.00541.x

[29] Bryne, J.C., Valen, E., Tang, M.H., Marstrand, T., Winther, O., da Piedade, I., Krogh, A., Lenhard, B. and Sandelin, A. (2008) JASPAR, the Open Access Database of Transcription Factor-Binding Profiles: New Content and Tools in the 2008 Update. Nucleic Acids Research, 36, D102-D106.

[30] Sandelin, A., Alkema, W., Engstrom, P., Wasserman, W.W. and Lenhard, B. (2004) JASPAR: An Open-Access Database for Eukaryotic Transcription Factor Binding Profiles. Nucleic Acids Research, 32, D91-D94.

[31] Sandelin, A., Wasserman, W.W. and Lenhard, B. (2004) ConSite: Web-Based Prediction of Regulatory Elements Using Cross-Species Comparison. Nucleic Acids Research, 32, W249-W252.

[32] Pennisi, E. (2011) The Biology of Genomes. Disease Risk Links to Gene Regulation. Science, 332, 1031. http://dx.doi.org/10.1126/science.332.6033.1031

[33] Kumar, V., Wijmenga, C. and Withoff, S. (2012) From Genome-Wide Association Studies to Disease Mechanisms: Celiac Disease as a Model for Autoimmune Diseases. Seminars in Immunopathology, 34, 567-580. http://dx.doi.org/10.1007/s00281-012-0312-1

[34] Hindorff, L.A., Sethupathy, P., Junkins, H.A., Ramos, E.M., Mehta, J.P., Collins, F.S. and Manolio, T.A. (2009) Potential Etiologic and Functional Implications of Genome-Wide Association Loci for Human Diseases and Traits. Pro- 
ceedings of the National Academy of Sciences of the United States of America, 106, 9362-9367. http://dx.doi.org/10.1073/pnas.0903103106

[35] Kumar, V., Westra, H.J., Karjalainen, J., Zhernakova, D.V., Esko, T., Hrdlickova, B., Almeida, R., Zhernakova, A., Reinmaa, E., Vosa, U., Hofker, M.H., Fehrmann, R.S., Fu, J., Withoff, S., Metspalu, A., Franke, L. and Wijmenga, C. (2013) Human Disease-Associated Genetic Variation Impacts Large Intergenic Non-Coding RNA Expression. PLoS Genetics, 9, Article ID: e1003201. http://dx.doi.org/10.1371/journal.pgen.1003201

[36] Chorley, B.N., Wang, X.T., Campbell, M.R., Pittman, G.S., Noureddine, M.A. and Bell, D.A. (2008) Discovery and Verification of Functional Single Nucleotide Polymorphisms in Regulatory Genomic Regions: Current and Developing Technologies. Mutation Research, 659, 147-157. http://dx.doi.org/10.1016/j.mrrev.2008.05.001

[37] Prokunina, L. and Alarcon-Riquelme, M.E. (2004) Regulatory SNPs in Complex Diseases: Their Identification and Functional Validation. Expert Reviews in Molecular Medicine, 6, 1-15. http://dx.doi.org/10.1017/S1462399404007690

[38] Buckland, P.R. (2006) The Importance and Identification of Regulatory Polymorphisms and Their Mechanisms of Action. Biochimica et Biophysica Acta, 1762, 17-28. http://dx.doi.org/10.1016/j.bbadis.2005.10.004

[39] Sadee, W., Wang, D., Papp, A.C., Pinsonneault, J.K., Smith, R.M., Moyer, R.A. and Johnson, A.D. (2011) Pharmacogenomics of the RNA World: Structural RNA Polymorphisms in Drug Therapy. Clinical Pharmacology \& Therapeutics, 89, 355-365. http://dx.doi.org/10.1038/clpt.2010.314

[40] Wan, Y.I., Shrine, N.R., Soler Artigas, M., Wain, L.V., Blakey, J.D., Moffatt, M.F., Bush, A., Chung, K.F., Cookson, W.O., Strachan, D.P., Heaney, L., Al-Momani, B.A., Mansur, A.H., Manney, S., Thomson, N.C., Chaudhuri, R., Brightling, C.E., Bafadhel, M., Singapuri, A., Niven, R., Simpson, A., Holloway, J.W., Howarth, P.H., Hui, J., Musk, A.W., James, A.L., Brown, M.A., Baltic, S., Ferreira, M.A., Thompson, P.J., Tobin, M.D., Sayers, I. and Hall, I.P. (2012) Genome-Wide Association Study to Identify Genetic Determinants of Severe Asthma. Thorax, 67, 762-768. http://dx.doi.org/10.1136/thoraxjnl-2011-201262

[41] Perin, P. and Potocnik, U. (2014) Polymorphisms in Recent GWA Identified Asthma Genes CA10, SGK493, and CTNNA3 Are Associated with Disease Severity and Treatment Response in Childhood Asthma. Immunogenetics, 66, 143-151. http://dx.doi.org/10.1007/s00251-013-0755-0

[42] Torgerson, D.G., Ampleford, E.J., Chiu, G.Y., Gauderman, W.J., Gignoux, C.R., Graves, P.E., Himes, B.E., Levin, A.M., Mathias, R.A., Hancock, D.B., Baurley, J.W., Eng, C., Stern, D.A., Celedon, J.C., Rafaels, N., Capurso, D., Conti, D.V., Roth, L.A., Soto-Quiros, M., Togias, A., Li, X., Myers, R.A., Romieu, I., Van Den Berg, D.J., Hu, D., Hansel, N.N., Hernandez, R.D., Israel, E., Salam, M.T., Galanter, J., Avila, P.C., Avila, L., Rodriquez-Santana, J.R., Chapela, R., Rodriguez-Cintron, W., Diette, G.B., Adkinson, N.F., Abel, R.A., Ross, K.D., Shi, M., Faruque, M.U., Dunston, G.M., Watson, H.R., Mantese, V.J., Ezurum, S.C., Liang, L., Ruczinski, I., Ford, J.G., Huntsman, S., Chung, K.F., Vora, H., Calhoun, W.J., Castro, M., Sienra-Monge, J.J., del Rio-Navarro, B., Deichmann, K.A., Heinzmann, A., Wenzel, S.E., Busse, W.W., Gern, J.E., Lemanske Jr., R.F., Beaty, T.H., Bleecker, E.R., Raby, B.A., Meyers, D.A., London, S.J., Gilliland, F.D., Burchard, E.G., Martinez, F.D., Weiss, S.T., Williams, L.K., Barnes, K.C., Ober, C. and Nicolae, D.L. (2011) Meta-Analysis of Genome-Wide Association Studies of Asthma in Ethnically Diverse North American Populations. Nature Genetics, 43, 887-892. http://dx.doi.org/10.1038/ng.888 


\section{Supplement}

Table 1. Transcriptional factor (TF) descriptions.

\begin{tabular}{|c|c|}
\hline TFs & TF description \\
\hline AR & $\begin{array}{l}\text { Steroid hormone receptors are ligand-activated transcription factors that regulate eukaryotic gene expression and } \\
\text { affect cellular proliferation and differentiation in target tissues. }\end{array}$ \\
\hline ARNT & Involved in the induction of several enzymes that participate in xenobiotic metabolism. \\
\hline ARNT:AHR & $\begin{array}{l}\text { The dimer alters transcription of target genes. Involved in the induction of several enzymes that participate in } \\
\text { xenobiotic metabolism. }\end{array}$ \\
\hline BRCA1 & $\begin{array}{l}\text { This gene encodes a nuclear phosphoprotein that plays a role in maintaining genomic stability, and it also acts as } \\
\text { a tumor suppressor. }\end{array}$ \\
\hline CREB1 & This gene encodes a transcription factor that is a member of the leucine zipper family of DNA binding proteins \\
\hline ELF5 & A member of an epithelium-specific subclass of the Ets transcritpion factor family. \\
\hline ELK1 & The protein encoded by this gene is a nuclear target for the ras-raf-MAPK signaling cascade. \\
\hline ELK4 & Involved in both transcriptional activation and repression. \\
\hline EN1 & Homeobox-containing genes are thought to have a role in controlling development. \\
\hline ETS1 & $\begin{array}{l}\text { The protein encoded by this gene belongs to the ETS family of transcription factors and has been shown to } \\
\text { interact with TTRAP, UBE2I and Death associated protein. }\end{array}$ \\
\hline FEV & It functions as a transcriptional repressor. \\
\hline FOXC1 & $\begin{array}{l}\text { This gene belongs to the forkhead family of transcription factors which is characterized by a distinct DNA-binding } \\
\text { forkhead domain. An important regulator of cell viability and resistance to oxidative stress. }\end{array}$ \\
\hline FOXL1 & $\begin{array}{l}\text { FOX transcription factors are characterized by a distinct DNA-binding forkhead domain and play critical roles in } \\
\text { the regulation of multiple processes including metabolism, cell proliferation and gene expression during ontogenesis. }\end{array}$ \\
\hline GATA2 & $\begin{array}{l}\text { A member of the GATA family of zinc-finger transcription factors that are named for the consensus nucleotide } \\
\text { sequence they bind in the promoter regions of target genes and play an essential role in regulating transcription } \\
\text { of genes involved in the development and proliferation of hematopoietic and endocrine cell lineages. }\end{array}$ \\
\hline GATA3 & Plays an important role in endothelial cell biology. \\
\hline HAND1:TCFE2 $\alpha$ & $\begin{array}{l}\text { Hand1 belongs to the basic helix-loop-helix family of transcription factors. The Tcfe2a gene encodes the } \\
\text { transcription factor E2A, a member of the "class I" a family of basic helix-loop-helix (bHLH) transcription } \\
\text { factors (also known simply as "E-proteins”). The transcription factor E2A controls the initiation of B lymphopoiesis. }\end{array}$ \\
\hline HIF1 $\alpha: A R N T$ & $\begin{array}{l}\text { HIF1 is a homodimeric basic helix-loop-helix structure composed of HIF1a, the alpha subunit, and the aryl } \\
\text { hydrocarbon receptor nuclear translocator (Arnt), the beta subunit. The protein encoded by HIF1 is a Per-Arnt-Sim } \\
\text { (PAS) transcription factor found in mammalian cells growing at low oxygen concentrations. It plays an essential } \\
\text { role in cellular and systemic responses to hypoxia. }\end{array}$ \\
\hline HLTF & $\begin{array}{l}\text { This gene encodes a member of the SWI/SNF family. Members of this family have helicase and ATPase activities } \\
\text { and are thought to regulate transcription of certain genes by altering the chromatin structure around those genes. }\end{array}$ \\
\hline $\mathrm{HNF} 4 \alpha$ & $\begin{array}{l}\text { The encoded protein controls the expression of several genes, including hepatocyte nuclear factor } 1 \text { alpha, } \\
\text { a transcription factor which regulates the expression of several hepatic genes }\end{array}$ \\
\hline INSM1 & This gene is a sensitive marker for neuroendocrine differentiation of human lung tumors. \\
\hline KLF4 & $\begin{array}{l}\text { Transcription factor that can act both as activator and as repressor. Regulates the expression of key transcription } \\
\text { factors during embryonic development. }\end{array}$ \\
\hline MAFB & The encoded nuclear protein represses ETS1-mediated transcription of erythroid-specific genes in myeloid cells. \\
\hline MAX & $\begin{array}{l}\text { The protein encoded by this gene is a member of the basic helix-loop-helix leucine zipper (bHLHZ) family of } \\
\text { transcription factors }\end{array}$ \\
\hline MZF1_1-4 & $\begin{array}{l}\text { Binds to target promoter DNA and functions as trancription regulator. May be one regulator of transcriptional } \\
\text { events during hemopoietic development. Isoforms of this protein have been shown to exist at protein level. }\end{array}$ \\
\hline MZF1_1-5-13 & $\begin{array}{l}\text { Binds to target promoter DNA and functions as trancription regulator. May be one regulator of transcriptional } \\
\text { events during hemopoietic development. Isoforms of this protein have been shown to exist at protein level. }\end{array}$ \\
\hline NFE2L1:MafG & $\begin{array}{l}\text { Nuclear factor erythroid 2-related factor (Nrf2) coordinates the up-regulation of cytoprotective genes via the } \\
\text { antioxidant response element (ARE). MafG is a ubiquitously expressed small maf protein that is involved in cell } \\
\text { differentiation of erythrocytes. It dimerizes with P45 NF-E2 protein and activates expression of a and b-globin. }\end{array}$ \\
\hline
\end{tabular}




\section{Continued}

$\begin{array}{ll}\text { Recognizes and binds the palindromic sequence 5'-TTGGCNNNNNGCCAA-3' present in viral and cellular } \\ \text { NFIC } & \text { promoters and in the origin of replication of adenovirus type } 2 \text {. These proteins are individually capable of }\end{array}$ activating transcription and replication.

NKX2-5 This gene encodes a member of the NK family of homeobox-containing proteins. Transcriptional repressor that acts as a negative regulator of chondrocyte maturation.

NOBOX This homeobox gene encodes a transcription factor that is thought to play a role in oogenesis.

NR2E3 This protein is part of a large family of nuclear receptor transcription factors involved in signaling pathways.

NR2F1 Coup (chicken ovalbumin upstream promoter) transcription factor binds to the ovalbumin promoter and, in conjunction with another protein (S300-II) stimulates initiation of transcription.

Glucocorticoids regulate carbohydrate, protein and fat metabolism, modulate immune responses through suppression

NR3C1 of chemokine and cytokine production and have critical roles in constitutive activity of the CNS, digestive, hematopoietic, renal and reproductive systems.

NR4A2 Transcriptional regulator which is important for the differentiation and maintenance of meso-diencephalic dopaminergic (mdDA) neurons during development.

PAX2 Probable transcription factor that may have a role in kidney cell differentiation.

SOX17 Acts as transcription regulator that binds target promoter DNA and bends the DNA.

Can activate or repress transcription in response to physiological and pathological stimuli. Regulates the expression of a large number of genes involved in a variety of processes such as cell growth, apoptosis, differentiation and immune responses.

SPI1 This gene encodes an ETS-domain transcription factor that activates gene expression during myeloid and B-lymphoid cell development.

SPZ1 This gene encodes a bHLH-zip transcription factor which functions in the mitogen-activate protein kinase (MAPK) signaling pathway.

TFAP2A The protein encoded by this gene is a transcription factor that binds the consensus sequence 5'-GCCNNNGGC-3' and activates the transcription of some genes while inhibiting the transcription of others.

USF1 This gene encodes a member of the basic helix-loop-helix leucine zipper family, and can function as a cellular. transcription factor.

YY1 Multifunctional transcription factor that exhibits positive and negative control on a large number of cellular and viral genes by binding to sites overlapping the transcription start site

ZEB1 This gene encodes a zinc finger transcription factor. Acts as a transcriptional repressor.

ZFX A member of the krueppel C2H2-type zinc-finger protein family and probable transcriptional activator.

ZNF354C May function as a transcription repressor. 